KINGA ROZWADOWSKA

Uniwersytet Jagielloński

kinga.rozwadowska@uj.edu.pl

\title{
POLIFONICZNOŚĆ PRZEKŁADU
}

\section{A POLIFONICZNOŚĆ POWIEŚCI. KONCEPCJE TRANSLATOLOGICZNE THEO HERMANSA W ŚWIETLE TEORII MICHAIŁA BACHTINA}

\section{Abstract \\ Polyphony in Translation and Polyphony in Novel: Theo Hermans' Translation Concept in the Context of Mikhail Bakhtin's Theory}

The aim of the paper is to discuss Theo Hermans' approach to translation as a quotation, presented in his book The Conference of the Tongues (2007) in the context of Mikhail Bakhtin's polyphony theory. Both concepts are based on the distinction between the voice of the reporter and the voice of the Other, and both argue that the relationship between them is significant.

Hermans understands translation as a "picture" of the original work and he identifies framing and embedded utterance within it. Framing means all kinds of paratexts, all forms of the translator's or publishers' comments accompanying a particular translation, while the embedded utterance is the translated text itself. This construction enables the author to draw a parallel between translation and reported speech. Hermans suggests eight types of reported speech, which range from paraleptic omission to free direct discourse. $\mathrm{He}$ argues that the way the reporter presents words of the Other matters and shows his/her attitude towards the reported ideas and values.

From this point of view, translation is presented as an impure, polyphonic text, where translator's voice is constantly confronting the values expressed in the original work and, therefore, is forced to negotiate them. Theo Hermans' concept is similar to Bakhtin's idea of "dialogical word" with its two voices meeting and confronting each other within one utterance. This proves that Bakhtin's polyphonic theory of the novel is functional in research within Translation Studies. 
Key words: literary translation, polyphony, paratext, Bachtin, Dostoyevsky

Słowa klucze: przekład literacki, polifonia, paratekst, Bachtin, Dostojewski

W ostatnich dekadach XX wieku i na początku XXI wieku można dostrzec wzrastające zainteresowanie badaczy przekładu osobą tłumacza i stopniową zmianę jego statusu z medium czy pośrednika na twórcę. Tłumacz przestaje być „przeźroczysty” i nabiera kształtów konkretnej osoby, której doświadczenie, przeżycia, pozycję społeczną czy też płeć możemy dostrzec w przekładanym tekście. Nowe koncepcje i próby uchwycenia i opisania głosu tłumacza sprawiają, że staje się on coraz lepiej słyszalny i coraz wyraźniej przemawia do nas poprzez tłumaczone dzieła. Postrzeganie przekładu jako tekstu wielogłosowego stanowi podstawę ujęcia zaprezentowanego w książce Narada języków Theo Hermansa, lecz sama koncepcja polifonii jest, jak wiadomo, starsza i ma swoje źródło w refleksji Michaiła Bachtina nad twórczością Dostojewskiego. Badacze niejednokrotnie zaznaczali, że terminologia stosowana w pracach Bachtina jest nieprzekładalna na języki teorii konkretnych dziedzin nauki (Bolecki 1977: 13; Ulicka 2001: 34). Niemniej jednak jego sposób myślenia o złożonej relacji między daną świadomością a Innym oraz o przejmowaniu i przekształcaniu słowa obcego w słowo własne wydaje się bardzo ważny dla pewnych nurtów współczesnego przekładoznawstwa. Niniejszy artykuł stanowi omówienie tez Theo Hermansa w kontekście teorii polifonii Bachtina, a jego celem jest wyjaśnienie, jak refleksje rosyjskiego myśliciela można wykorzystać w badaniach translatologicznych.

W ostatnich latach ukazały się w Polsce dwie ważne prace poświęcone zagadnieniom polifonii i przekładu, a każda pierwszy z tych terminów definiuje w odmienny sposób. Karolina Dębska w swojej rozprawie Tekst polifoniczny jako przedmiot tłumaczenia literackiego posłużyła się pojęciem polifonii przeniesionym na grunt przekładoznawstwa i zawężonym do perspektywy socjolingwistycznej: „W obecnej pracy teksty polifoniczne to takie, w których łączą się różne odmiany językowe: dialekty, socjolekty, odmiany związane z wiekiem, gwary zawodowe lub subkulturowe, cytaty stylistyczne i obce akcenty, itp.” (Dębska 2012: 5). Z kolei Magdalena Pytlak, autorka książki Polifoniczność w przekładzie. O tym, jak Polacy i Bułgarzy czytaja ,Biesy” Dostojewskiego, wykorzystała Bachtinowską interpretację twórczości Dostojewskiego jako autora powieści polifonicznej. Jej badania skupiają się wokół przedstawionej w Problemach poetyki Dostojewskiego 
typologii słowa prozatorskiego oraz sposobów ich odtworzenia i przekształcenia w polskich i bułgarskich przekładach Biesów.

Refleksje Bachtina nad twórczością Dostojewskiego będą jednym $\mathrm{z}$ głównych przedmiotów analizy również w niniejszym artykule, choć w innym ujęciu. Uznawana dziś za kanoniczną, interpretacja Bachtina przedstawiona została najpierw w pracy Problemy tworczestwa Dostojewskogo w roku 1929 (polski przekład Wincentego Grajewskiego ukazał się w 2009 roku), a jej poszerzone wydanie, noszące tytuł Problemy poetiki Dostojewskogo, opublikowano w 1963 roku (w Polsce w thumaczeniu Natalii Modzelewskiej - w 1970 roku). Polifoniczna zasada poetyki Dostojewskiego rozpatrywana jest tu na czterech płaszczyznach: 1. na płaszczyźnie relacji: autor - bohaterowie; 2. na płaszczyźnie idei w dziele Dostojewskiego; 3. na płaszczyźnie gatunkowych i fabularno-kompozycyjnych właściwości utworów; 4. na płaszczyźnie typów słowa prozatorskiego. Ze względu na nakreślony powyżej temat artykułu, najbardziej będzie mnie interesować pierwsze zagadnienie, dotyczące statusu podmiotu twórczego w tekście, pominę zagadnienie drugie i trzecie, natomiast temat czwarty, dotyczący słowa w powieści, spróbuję rozpatrzyć nie jako „wskazówkę stylistyczną” dla tłumaczy, lecz jako bardziej uniwersalny opis sposobów spotykania się z Innym poprzez przekład. Zagadnienie to łączy w mojej opinii Bachtinowską filozofię ze współczesnymi nurtami przekładoznawstwa, o czym będzie mowa w ostatniej części artykułu.

W odniesieniu do pierwszego z wyżej wymienionych zagadnień Bachtin określa nowatorstwo Dostojewskiego jako pomysł oparty na uniezależnieniu bohaterów od autora. Bohaterowie ci przestają być traktowani przedmiotowo, przestają być środkiem do wyrażenia ogólnie pojętej idei autorskiej, a stają się niezależnymi i równoprawnymi wobec autora podmiotami, prezentującymi odrębne i suwerenne punkty widzenia. Bachtin zauważył, że pozycja Dostojewskiego-autora wobec bohaterów jego dzieł jest pozycją dialogową: „Dla autora bohater - to nie «on», nie «ja», lecz równorzędne «ty», czyli inne, cudze, równouprawnione «ja»" (Bachtin 1970: 96). Aby umożliwić swoim bohaterom niezależny byt, sam autor zmuszony jest nieustannie poszerzać swoją świadomość o inne świadomości:

Autor powieści polifonicznej nie musi wyrzekać się siebie, swojej świadomości - musi ją jedynie ogromnie poszerzyć, pogłębić i przebudować (co prawda w określonym kierunku), żeby mogła zmieścić równorzędne świadomości cudze (Bachtin 1970: 104). 
Autor, przy zachowaniu własnej tożsamości, ma wchłonąć również wszystkie inne przedstawione w dziele punkty widzenia. W ujęciu Bachtinowskim koncepcja Dostojewskiego polega na pozbawieniu siebie samego władzy nad tworzonymi postaciami. Idea polifoniczności pozwala pisarzowi zdystansować się od swojego światopoglądu i zrównać własne idee $\mathrm{z}$ innymi $\mathrm{w}$ dialogu.

Równocześnie Bachtin porusza w swojej interpretacji kwestię ,,autorytetu" oraz jego funkcji w dziełach pisarza:

Wśród nich [postaw ludzkich - K.R.] chce autor wyróżnić postawę o największym autorytecie - nie po to, żeby stała się odbiciem jego własnej wizji prawdy, tylko żeby myślą i słowem dała świadectwo prawdzie innego człowieka (Bachtin 1970: 149).

Teza o „głosie nadrzędnym”, którego zadaniem nie jest przemawianie w imieniu autora, lecz selekcja i uporządkowanie głosów pozostałych, rozwijana jest w następujący sposób:

(...) nadrzędny głos powinien był zestroić, podporządkować sobie i uwieńczyć harmonią cały świat głosów (...). Ma on tylko kierować doborem i układaniem materiału (...), natomiast materiał składa się z cudzych głosów, z cudzych punktów widzenia (Bachtin 1970: 149-152).

Choć Bachtin kilkakrotnie podkreśla, że owego głosu nadrzędnego nie należy utożsamiać $\mathrm{z}$ głosem autora, to przyznaje, że w polifonicznym świecie powieści Dostojewskiego istnieje pewnego rodzaju autorytet, że „Wszechwładna idea” niebezpośrednio wpływa na pozostałe postacie-idee. Fakt, że nie jest to prawda w rozumieniu systemowym, co mocno zaznacza Bachtin, lecz prawda przyjmująca postać autorytetu moralnego, nie zmienia ogólnej zasady: „nastawienie idealne na słowo prawdy” (Bachtin 1970: 150) ma być nakierowaniem pozostałych głosów na dialog z jednym głosem nadrzędnym.

Kwestia autorytetu moralnego, nie tożsamego z głosem autora, a jednak wyraźnie wyniesionego ponad pozostałe głosy, powraca w zakończeniu rozprawy Michaiła Bachtina. Myśliciel wyodrębnia ,słowo żywotów świętych” jako jedną z odmian słowa w powieściach Dostojewskiego: „Jest to słowo bez oglądania się na innych, wyrażające z całym spokojem siebie i swój przedmiot" (Bachtin 1970: 375). Mowa więc o pierwszym rodzaju słowa wymienionym w typologii Bachtina - o słowie bezpośrednio skierowanym na swój przedmiot, niezdialogizowanym. Ten głos jest znamienny 
dla bohaterów, którzy ,zdaniem autora” (wyrażenie Bachtina) dochodzą do prawdy i zaczynają przemawiać własnym, silnym, pełnym i oczyszczonym z obcego słowa głosem. Osobnym, choć pokrewnym rodzajem tego słowa jest tak zwane słowo natchnione, które również ma być ,homofonicznie spoiste, nierozszczepione, ma być słowem bez oglądania się, bez uników, bez polemiki wewnętrznej" (Bachtin 1970: 377). W przytoczonym cytacie sugestia istnienia głosu funkcjonującego na innych prawach niż pozostałe, homofonicznego głosu władzy, jest jeszcze bardziej wyraźna.

Zwracają tu uwagę dwa stwierdzenia: 1) istnieje ,zdaniem autora” prawda, którą bohater może osiągnąć; 2) w momencie osiągnięcia prawdy bohater przemawia innym głosem niż pozostali bohaterowie i narrator - odrębnym, niezależnym głosem władzy. To on staje się wspomnianym wyżej autorytetem moralnym, wobec i do którego mają przemawiać pozostałe głosy.

Napięcie pomiędzy homofonią a polifonią w dziele Dostojewskiego nie musi być jednak postrzegane jako sprzeczność. Włodzimierz Bolecki trafnie napisał, że w refleksji Bachtina obydwa pojęcia są względem siebie komplementarne i nie należy ich traktować jako odrębnych, ściśle rozgraniczonych zjawisk (Bolecki 1977: 15). Niemniej warto zauważyć, że problem obecności i sposobu istnienia głosu homofonicznego - głosu autorskiego w powieści polifonicznej - do dziś budzi kontrowersje, a na temat granic polifonii obszernie wypowiadał się między innymi Czesław Miłosz: „Jego polifoniczność ma jednak granice. Za nią ukrywa się żarliwy wyznawca, rosyjski millenarysta i mesjanista; Trudno o coś bardziej jednogłosowego niż scena z Polakami w Braciach Karamazow, płaska satyra nielicująca z powagą tego dzieła" (Miłosz 2010: 101). Pytanie o to, w jakim stopniu autor sprawuje kontrolę nad głosami zderzającymi się w powieści polifonicznej i w jakim stopniu jego władza wiąże się $\mathrm{z}$ ich uprzedmiotowieniem, dotyczy w szerszej perspektywie problemu możliwości niezdeterminowanego spotkania z Innym. Aby rozważyć tę kwestię, należy w tym miejscu uważniej przyjrzeć się fundamentalnemu warunkowi zaistnienia polifonii, a mianowicie Bachtinowskiej koncepcji słowa dialogicznego.

Pisząc o dwugłosowej naturze słowa jako o podstawowej zasadzie poetyki Dostojewskiego i, szerzej, polifonii, Bachtin zauważa: „Wprowadzone do naszej mowy cudze słowo nieuchronnie nasiąka nową, naszą interpretacją i oceną, czyli staje się dwugłosowe" (Bachtin 1970: 295), to jest równocześnie własne i obce. Przyswojenie cudzego słowa i nadanie mu nowego wydźwięku jest podstawą ironii, parodii, stylizacji. W tym sensie wszystkie 
rodzaje należące do trzeciej kategorii słowa w typologii Bachtina odznaczają się w mniejszym lub większym stopniu predyspozycją do dominacji. Taki opis mechanizmów przyswajania będzie wybrzmiewał później w badaniach postkolonialnych i znajdzie wyraz w dosadnej metaforyce kanibalistycznej. Obcy musi zostać pochłonięty, zniszczony w swej prymarnej formie, aby mógł się odrodzić, a dokładniej, aby pewne jego właściwości mogły przemówić w nowym ciele, w innej postaci. W koncepcji Bachtina słowo, aby stać się dwugłosowe, musi zostać wyrwane ze swojego kontekstu, następnie zaś może być użyte do innych, niekiedy nawet sprzecznych z pierwotnymi, celów. Podobnie - jak wskazałam powyżej - pisze Bachtin o autorze powieści polifonicznej, który musi nieustannie poszerzać swoją świadomość o cudze świadomości. Umiejętność przemawiania innymi głosami nie pozbawia go jednak własnej podmiotowości.

Omówienie wybranych aspektów rozprawy Michaiła Bachtina Problemy poetyki Dostojewskiego miało na celu wydobycie i podkreślenie momentów, w których wielogłosowość nie jest równoznaczna z harmonią i równością. Polifonia może się wiązać również z wchłanianiem i (pod)porządkowaniem głosów pozostałych, bez konieczności ich uprzedmiotowienia. Wnioski te okazują się przydatne przy próbie rozpatrywania wielogłosowości przekładanego dzieła w takim ujęciu, jakie proponuje Theo Hermans w swojej rozprawie Narada języków.

Theo Hermans jest badaczem kojarzonym przede wszystkim ze „szkołą manipulistów" we współczesnych naukach o przekładzie. Nurt ten, powstały z końcem lat 70. ubiegłego wieku, na podstawie teorii polisystemu Itamara Even-Zohara proponuje badania opisowe skupiające się na funkcjonowaniu przekładu w kulturze docelowej zamiast na poszukiwaniu ekwiwalencji względem oryginału (niemożliwej zresztą zdaniem manipulistów do osiągnięcia), zrywając w ten sposób z tradycyjnym lingwistycznym podejściem do zjawiska przekładu (Bukowski, Heydel 2009: 295).

Z perspektywy omawianego tu poglądu Michaiła Bachtina na polifonię szczególnego znaczenia nabiera książka Hermansa Narada języków, opublikowana w 2007 roku (polski przekład wydano w roku 2015). Badacz, kwestionując możliwość osiągnięcia ekwiwalencji w przekładzie, prezentuje koncepcję tłumaczenia jako zjawiska z natury „nieczystego” i wielogłosowego, którego twórca - tłumacz - ma decydujący wpływ na sposób przedstawienia oryginału czytelnikom. Kluczowy dla tego podejścia jest rozdział Echo ironii, w którym badacz uzasadnia istnienie głosu tłumacza oraz jego znaczenie dla odbioru tłumaczonego tekstu, rozpatrując przekład jako cytat. 
Obecności głosu tłumacza w przekładanym dziele Hermans dowodzi na wyrazistym przykładzie dwóch tłumaczeń Mein Kampf Adolfa Hitlera, w których pytanie o to, kim jest ,ja” przemawiające do czytelnika w przekładzie, nabiera szczególnego znaczenia. Obydwa teksty postrzegane są przez badacza jako całościowy obraz dzieła tłumaczonego: równie ważne jest dla niego ,wypełnienie” (embedded utterance), czyli sam tekst przekładu, jak i „obramowanie” (framing utterance), to jest wszelkiego rodzaju parateksty, jakimi tłumacze bądź wydawcy opatrują konkretne tłumaczenie. Te dwa elementy są z sobą ściśle powiązane i należy je rozpatrywać łącznie: „Bezpośredni wpływ na jego [tłumaczenia - KR] wymowę mają ramy tekstowe, które je otaczają" (Hermans 2015: 76). Autor zauważa, że obramowanie tekstu umożliwia między innymi odcięcie się od tego, co obce, i opowiedzenie za rodzimymi wartościami wtedy, kiedy idee zawarte w tłumaczonym tekście stoją w sprzeczności z wartościami wyznawanymi przez twórcę tłumaczenia. Hermans powołuje się na przekłady Mein Kampf jako najdobitniej potwierdzające problem konfliktu wartości, który mocno wpływa na przekład i jego odbiór. Przywołane przez Hermansa teksty są przypadkami skrajnymi: w jednym przypadku tłumacz całkowicie identyfikuje się z poglądami autora oryginału, w drugim grupa tłumaczy radykalnie się od nich odcina. Struktura przekładu, jako rama i jej wypełnienie, przypomina zatem cytowanie i w ten sposób interpretowana prowokuje pytanie: kto jest odpowiedzialny za przytaczane słowa? Rozstrzygając tę wątpliwość, badacz ujmuje przekład w kategoriach mowy zależnej i mowy niezależnej a opierając się na licznych przykładach z literatury światowej, przekonuje, że sprawozdawca nie może być obarczany odpowiedzialnością za przytoczenie. Nałożenie na niego takiej odpowiedzialności równałoby się utożsamieniu głosu autora przekładu z głosem autora oryginału, uniemożliwia to jednak obramowanie przekładu, w którym głos tłumacza narzuca perspektywę i ton całemu thumaczeniu:

Jako że przedmowa thumacza nie przestaje pobrzmiewać w thumaczonym dyskursie, przypomina nam ona o podzielnej, nieczystej i wielogłosowej naturze przekładu. W przekładzie da się słyszeć więcej niż jeden głos, nawet jeśli przekładowa ideologia jako pewna historyczno-społeczna konstrukcja dąży do neutralizacji i wyciszenia tej różnorodności (Hermans 2015: 98).

Hermans zdecydowanie sprzeciwia się powszechnej opinii, że tłumacz zawiesza, a przynajmniej powinien zawiesić, własną tożsamość wtedy, gdy przystępuje do tłumaczenia tekstu. Zarówno bowiem komentarz tłumacza, 
jak i brak takiego komentarza świadczą o konkretnej postawie względem oryginału - im mniej tłumacz wypowiada uwag na temat prezentowanego tekstu, tym bardziej stara się schować w cieniu autora, ukryć fakt przekładu, by zaprezentowane w tekście wartości wybrzmiały jak najpełniej. Tak dzieje się w niderlandzkim przekładzie Mein Kampf autorstwa Stevena Barendsa, który opatrzony jest jedynie informacją o tym, że jest to wersja autoryzowana, a zatem powinna być odczytywana jako usankcjonowany ekwiwalent słów Hitlera.

W zaprezentowanym powyżej sposobie myślenia o przekładzie widać wyraźne ślady refleksji Bachtina nad znaczeniem kontekstów dla wypowiedzi. Rosyjski myśliciel w Słowie w powieści pisał: „Kontekst otaczający cudze słowo tworzy dialogizujące tło, którego wpływ może być znaczny. Wybierając odpowiednie sposoby obudowywania, można uzyskać bardzo istotne przekształcenie cudzej wypowiedzi skądinąd ściśle przytoczonej” (Bachtin 1982: 180). W Naradzie języków Hermans niejednokrotnie zresztą powołuje się na Bachtina, a pisząc o możliwości hermeneutycznego badania różnych ,pozycji podmiotowych przyjmowanych przez tłumaczy i autorów w dyskursie przekładowym”, stwierdza: „rozpoznania Michaiła Bachtina dotyczące literatury polifonicznej mogą się okazać lepszym modelem pod względem analizy zagadnienia hybrydyczności przekładu” (Hermans 2015: 191).

Struktura przekładu jako ramy i jej wypełnienia pozwala Hermansowi przeprowadzić analogię pomiędzy thumaczeniem a dyskursem przytoczonym w mowie zależnej, pozornie zależnej lub niezależnej. Budowa przekładu umożliwia bowiem również wyodrębnienie pierwotnego nadawcy i sprawozdawcy jako dwóch osobnych głosów. Ze względu na różne możliwości przytoczenia cudzej wypowiedzi w trzech wymienionych powyżej kategoriach, precyzyjne rozdzielenie i opis obydwu głosów mogą być niekiedy trudne. Hermans przekonuje, że przekład jest mieszaniną mowy zależnej i niezależnej, zatem wszelkie próby zamknięcia go w jednej z powyższych kategorii muszą być niezadowalające. Jako alternatywę badacz przywołuje ośmiostopniowy model stworzony przez Kristiinę Taivalkoski-Shilov, który stanowi swego rodzaju ruchomą skalę stopnia manipulacji mową przytoczoną. Model ten obejmuje następujące etapy:

1. Paraliptyczne streszczenie lub pominięcie, kiedy sprawozdawca odnosi się do czyichś istniejących słów, lecz je omija.

2. Diegetyczne streszczenie, czyli streszczenie czyjegoś dyskursu przez sprawozdawcę. 
3. Diegetyczną relację, czyli relacjonowanie czyichś słów przy użyciu słownictwa i stylu relacjonującego.

4. Dyskurs pozornie zależny, który jest pełną reprezentacją czyichś słów, lecz głównie przy użyciu słownictwa i tonacji sprawozdawcy.

5. Mimetyczny dyskurs zależny, czyli formę mowy zależnej, która zachowuje rejestr i stylistyczną fizjonomię mowy przytoczonej.

6. Dyskurs pozornie niezależny, czyli mimetyczną reprezentację czyichś słów, lecz bez dyskursu ją obramowującego.

7. Dyskurs niezależny, czyli mimetyczną reprezentację uprzedniego dyskursu, zwykle w cudzysłowie, osadzoną w diegetycznym dyskursie tworzonym przez sprawozdawcę, lecz syntaktycznie autonomicznym.

8. Dyskurs pozornie zależny, czyli mowę niezależną, lecz pozbawioną obramowującego zdania głównego (Hermans 2015: 93-95).

Stopnie przedstawionego powyżej modelu płynnie się z sobą łączą, oscylując pomiędzy całkowitą i minimalną władzą sprawozdawcy nad przytoczonym dyskursem, przy czym, jak podkreśla Hermans: „Kontrola sprawozdawcy lub tłumacza nad dyskursem relacjonowanym może być całkowita, tak jak w przypadku całkowitego pomięcia (streszczenie paraliptyczne). Na drugim końcu skali nie znajduje się jednak zero" (Hermans 2015: 96).

Sposób ujęcia przekładu zaproponowany przez Theo Hermansa przywodzi na myśl Bachtinowską klasyfikację słowa w dziele literackim właśnie ze względu na relację: słowo własne - słowo Innego. Słowo autora w ujęciu Bachtina kształtuje się pod wpływem cudzego słowa i oscyluje pomiędzy całkowitym uprzedmiotowieniem i dialogiem (niekiedy równoznacznym z konfliktem). Poniżej przytoczę typologię Bachtina, akcentując te jej aspekty, które korespondują z modelem badawczym Hermansa, po to, by pokazać, jak Bachtinowskie myślenie o dialogu z Innym może być zastosowane do opisywania mechanizmów funkcjonowania przekładu.

Klasyfikacja Bachtina obejmuje trzy kategorie słowa, z czego pierwsze dwie dotyczą słowa jednogłosowego, natomiast trzecia - słowa dwugłosowego. Kategoria trzecia podzielona została na dwie subkategorie: słowa jednokierunkowego i dwukierunkowego.

Pierwsza kategoria dotyczy „słowa bezpośrednio skierowanego na przedmiot”. Jest to słowo „wyrażające ostateczną pozycję myślową mówiącego" (Bachtin 1970: 301), ,słowo nazywające, informujące, wyrażające, obrazujące" (Bachtin 1970: 283). Tego rodzaju słowem posługuje się najczęściej autor tradycyjnej powieści homofonicznej, bezpośrednio przekazujący swoje 
stanowisko i sądy. Mowa autorska stanowi „najwyższą instancję myślową, a więc i najwyższą pozycję stylistyczną" (Bachtin 1970: 284). Wydaje się, że podobnie można scharakteryzować oryginał jako dzieło jednego autora, który w wybrany przez siebie sposób bezpośrednio komunikuje się z odbiorcą.

Drugą kategorią jest słowo uprzedmiotowione - w tradycyjnej powieści jest to słowo przedstawionej postaci. Choć samodzielnie tworzy również mowę ukierunkowaną na przedmiot, słowo to samo w sobie jest obiektem podlegającym autorowi:

To cudze ukierunkowanie [autora względem słów bohatera - K.R.] nie sięga wewnątrz słowa uprzedmiotowionego: operuje nim jako całością i nie zmieniając jego znaczenia i tonacji, podporządkowuje je swojemu zdaniu (Bachtin 1970: 286).

Słowo drugiego typu jest zatem słowem zobrazowanym, przedstawionym przez autora i w pełni podporządkowanym jego intencjom: „Mowa bohaterów nie tylko wyraża swój przedmiot, ale też sama stanowi przedmiot ukierunkowania jako słowo charakterystyczne, typowe, malownicze" (Bachtin 1970: 283). W tej przestrzeni autor dzieła staje się poniekąd tłumaczem, przytaczającym w mowie zależnej, niezależnej lub pozornie zależnej słowa postaci, w istocie sprawującym jednak nad nimi całkowitą kontrolę.

Trzeci typ słowa można odnieść do przekładu rozumianego - jak postuluje Hermans - jako zjawisko dwugłosowe. Drugi głos pojawia się zdaniem Bachtina w słowie, które „w intencji autora powinno brzmieć jak cudze” (Bachtin 1970: 287). Zostaje na nim nadpisane dodatkowe znaczenie, wykraczające poza oznaczenie przedmiotu. Autor przejmuje słowo wyrażające dany przedmiot i wykorzystuje je dla własnych celów, jednak proces ten różni się zasadniczo od kontroli, jaką autor sprawuje nad słowem postaci. Bachtin wyjaśnia tę różnicę, porównując słowo postaci (typ 2.) ze słowem narratora-opowiadacza (typ 3.):

Przecież autorowi chodzi nie tyle o właściwy opowiadaczowi indywidualny czy typowy sposób myślenia, odczuwania czy mówienia, ile przede wszystkim - o jego sposób patrzenia na rzeczy $i$ ich opisywania: na tym polegają jego bezpośrednie funkcje jako zastępcy autora. (...) ujęcie autora przenika $\mathrm{w}$ głąb jego słowa, czyniąc je w tym lub innym stopniu umownym (Bachtin 1970: 288).

Zasadnicza różnica polega więc na tym, że autor, przejmując cudze słowo, nie uprzedmiotawia go, lecz czyni umownym. Drugą kluczową różnicą jest sygnalizowany dystans: 
Autor nie obrazuje słowa opowiadacza (jak to czyni z uprzedmiotowionym słowem bohatera), lecz od wewnątrz dysponuje nim dla swoich celów, wyraźnie dając czytelnikom do zrozumienia, że między nim a tamtym cudzym głosem istnieje dystans (Bachtin 1970: 289).

Ujawnienie dystansu przypomina przypadek tłumaczenia, którego autor sprzeciwia się ideom przedstawionym w oryginale (tak jak we wspomnianym przez Hermansa anglojęzycznym przekładzie Mein Kampf): „Należy więc odróżnić postać, której głos zostaje wyartykułowany, od samego podmiotu artykułującego - ten drugi bowiem nalega na utrzymanie dystansu wobec sylwetki poprzednika, przy czym uwidacznia się to już nawet w sposobie modulacji tekstu" (Hermans 2015: 74). Wyraźne oddzielenie sprawozdawcy od wypowiedzi „demonstrowanej” (by użyć wyrażenia Hermansa) znamionuje taką metodę przedstawienia cudzych słów, którą autor Narady języków nazywa mimetyczną. Trzeba w tym miejscu wyjaśnić różnice terminologiczne pomiędzy „naśladownictwem” w rozumieniu Hermansa a „naśladownictwem” w ujęciu Bachtina. Pojęcia te przytaczane są przez badaczy w zupełnie różnych kontekstach. Dla Hermansa mimesis jako przeciwieństwo diegesis odnosi się przede wszystkim do rozróżnienia przekładu (wypełnienia) i komentarza (ramy). W tym kontekście Hermans wypowiada znamienne, kluczowe dla swoich badań słowa:

Zauważanie tej różnicy wiąże się także $\mathrm{z}$ dostrzeganiem odpowiedzialności etycznej i społecznej tłumacza. Podczas gdy tłumacze mogą się zrzekać odpowiedzialności za odtwarzanie czyjegoś dyskursu w formie mowy niezależnej, mogą zostać pociągnięci do odpowiedzialności za diegetyczny aspekt swojego mimesis. Do nich bowiem należy decyzja o podjęciu się tłumaczenia, prezentacja odegranego tekstu oraz wartościująca ocena, które przenikają całe wykonanie (Hermans 2015: 108-109).

W kontekście zjawiska polifonii (nie tylko w przekładzie) ważne jest oddzielenie przez Hermansa odpowiedzialności autora (oryginału/przekładu) za przedstawione przez niego wartości od postawy etycznej wobec nich. Ta druga obecna jest nie w samym tekście, lecz w tym, co go „otacza”.

$\mathrm{W}$ pracy Bachtina pojęcie naśladownictwa pojawia się $\mathrm{W}$ znaczeniu o wiele węższym niż u Hermansa i stanowi opozycję do stylizacji jako formy słowa dwugłosowego. W tym ujęciu stylizacja „cudzą koncepcję artystyczno-przedmiotową podporządkowuje celom własnym, czyli nowej koncepcji” (Bachtin 1970: 287), podczas gdy naśladownictwo „nie przemienia danej formy w umowną, bo samo traktuje pierwowzór na serio, przywłaszcza go 
sobie, bezpośrednio adaptuje cudze słowo" (Bachtin 1970: 288). Ze wskazanej powyżej różnicy kontekstów wynika pozorna sprzeczność założeń Bachtina i Hermansa: dla drugiego z nich naśladownictwo jest czymś „nie na serio", ujmowaniem w nawias, zawieszeniem naturalnego zachowania i ukryciem swojego ,ja” (Hermans 2015: 86). Sprzeczność ta wynika jednak z rozbieżności perspektyw: poetyki i retoryki. Zgodnie natomiast badacze uznają istnienie dystansu pomiędzy intencją autora a słowem Innego.

Dystans, jak widać w przytoczonym powyżej cytacie, pojawia się w przypadku Bachtinowskiego słowa dwugłosowego, kiedy autor, nieuprzedmiotowiając słów Innego, czyni je umownymi. W pracy Theo Hermansa dystans jest podstawą ironii:

Ironia zachodzi, gdy mówiący sygnalizuje: (a) że odnosi się do istniejącej wypowiedzi lub opinii, (b) że ma do niej jakiś określony stosunek, (c) że jest to wyraz dezaprobaty. Ironia zostaje wyróżniona przez akt zdystansowania się osoby mówiącej wobec opinii lub słów, do których się odnosi (Hermans 2015: 98).

Koncepcja ta, oparta na badaniach Dana Sperbera i Deirdre Wilson, znajduje pełne potwierdzenie w Bachtinowskiej perspektywie dwugłosowości. Autor Problemów poetyki Dostojewskiego porównuje działanie słowa ironicznego do słowa parodystycznego:

Do słowa parodystycznego zbliża się słowo ironiczne oraz wszelkie słowo cudze użyte w znaczeniu podwójnym, bowiem w takich wypadkach cudze słowo jest wykorzystywane w kierunku sprzecznym $\mathrm{z}$ jego naturalną tendencją (Bachtin 1970: 294).

Parodia w typologii Bachtina należy do subkategorii słów różnokierunkowych. W sytuacji konfliktu głosów, jak stwierdza Bachtin, nie wystarcza już ujawnienie dystansu, lecz wyraźne i dobitne określenie zarówno głosu autorskiego, jak i głosu cudzego. W podobny sposób o ironii pisze Hermans, powołując się zresztą na Słowo w powieści Bachtina:

Ironia pozwala osobie ironizującej, a w tym wypadku tłumaczowi, oprzeć się przed przyswojeniem własnego i ironizowanego dyskursu i w ten sposób podważyć autorytet tego drugiego oraz osłabić jego siłę perswazyjną. Ten niezharmonizowany stosunek zostaje zapowiedziany wcześniej u Bachtina w tekście Stowo w powieści z lat 1934-1935 (Hermans 2015: 101-102).

Tak jak tłumacz pozbawia oryginał władzy narzucania znaczeń i nadaje mu własny ton i brzmienie, tak autor dzieła polifonicznego przybiera pew- 
ną konwencję, styl, formę, aby dostosować ją „od wewnątrz” do własnej niewypowiedzianej myśli. Napięcie pomiędzy wypowiedzianym i niewypowiedzianym jest zdaniem Hermansa podstawową zasadą ironii: „Ironia działa w sytuacji komunikacyjnej, w której element wypowiedziany wywołuje ten, który pozostał niewypowiedziany" (Hermans 2015: 101). Według Hermansa przekład ma właściwie strukturę dyskursu ironicznego:

Formalnie rzecz ujmując, przekład ma strukturę dyskursu ironicznego, w którą jest wbudowany pewien stosunek wartościujący. Stosunek ten wpisuje się we właściwe tłumaczenie i komentuje je, przy czym różnica pomiędzy komentarzem a przekładem, między diegesis a mimesis, staje się istotna (Hermans 2015: 108).

Bachtin wyjaśnia dialogową naturę słowa na przykładzie mowy potocznej, kiedy to powtarzamy cudze słowa nierzadko z przeciwną intencją, nadając im inne brzmienie $\mathrm{w}$ nowym kontekście. Słowa formalnie pozostają niezmienione, lecz w cudzych ustach i w odmiennej sytuacji wypowiadania znaczą już coś innego. $Z$ tego powodu, jak zauważy później Hermans, cytaty muszą być czymś więcej niż tylko powtórzeniem, a przekłady - czymś więcej niż mową niezależną. Intencja towarzysząca powtórzeniu cudzych słów może być zgodna $\mathrm{z}$ ich pierwotnym wydźwiękiem (jak w słowach dwugłosowych jednokierunkowych, np. stylizacji, lub w thumaczeniu, którego autor aprobuje wartości tłumaczonego tekstu) albo z nimi sprzeczna (jak w słowach dwugłosowych różnokierunkowych, np. parodii, lub w tzw. thumaczeniu polemicznym). Hermans trafnie więc zauważa: „Na pograniczu między ramą tekstową a odtworzeniem przekładu tkwi potencjał, w którym mieszczą się zarówno rozdźwięk, jak i harmonia" (Hermans 2015: 98).

Istnieje jednak jeszcze trzecia podkategoria słowa nastawionego na cudze słowo. Bachtin przedstawia ją następująco:

W trzeciej odmianie cudze słowo pozostaje poza obrębem mowy autorskiej, która jednak uwzględnia je i jest na nie nastawiona. Słowu cudzemu nie nadaje się tu interpretacji własnej, za to - choć nieobecne - wpływa ono na słowo autorskie, w ten czy inny sposób je kształtuje (Bachtin 1970: 295).

Ponownie nasuwa się $\mathrm{w}$ tym miejscu skojarzenie z późniejszą teorią kanibalistyczną, w której unicestwiony obcy zmienia słowo autora „od środka". Relacja dominacji i zależności jest tu jednak znacznie bardziej złożona, a sam Bachtin nazywa tę odmianę słowa dwugłosowego „aktywną” 
- w porównaniu do dwóch pozostałych. Porównując stylizację i parodię do dialogu i ukrytej polemiki jako przykładów słowa dwukierunkowego trzeciego typu, Bachtin stwierdza:

(...) w stylizacji, w ustnej narracji i w parodii słowo cudze jest całkowicie bierne w ręku operującego nim autora. Autor, rzec można, zagarnia bezbronne, niezdolne do oporu cudze słowo, nadaje mu nowe znaczenie i każe służyć nowym celom autorskim. Natomiast w ukrytej polemice i w dialogu cudze słowo aktywnie oddziałuje na mowę autorską, zmuszając ją, by pod jego wpływem odpowiednio się zmieniała (Bachtin 1970: 299).

Wydaje mi się, że powyższy cytat można odnieść do sytuacji przekładu w relacji do kultury źródłowej i docelowej. Podczas gdy w pierwszych dwóch przypadkach tłumacz zagarnia tekst wyjściowy dla interesów własnych lub własnej kultury, trzecia odmiana słowa zakłada oddziaływanie w kierunku przeciwnym, kiedy to tłumacz pozwala „obcemu” kształtować tekst „od wewnątrz”, a przez to pośrednio przekształcać kulturę przyjmującą. Zapewne jest to założenie w jakiejś mierze utopijne, trzeba bowiem pamiętać, że niezależnie od tego, do jakiego stopnia tłumacz może pozwolić przemówić Innemu, nigdy nie będzie w stanie zawiesić na ten czas własnej tożsamości, zawsze istniejącej ,wobec” obcego:

Przy ujęciu przekładu jako złożonej formy cytowania staje się jasne, że ma on znaczenie społeczne i historyczne nie tylko dlatego, że jest nośnikiem dóbr kultury, ale także z powodu określonego kąta widzenia i oceny, które towarzyszą ich przekazywaniu (Hermans 2015: 106).

Ocena wartości wpisana jest w każdy przekład i zapewne również w powieść polifoniczną. Podstawowy rozdźwięk pomiędzy polifonicznością w ujęciu Bachtina a koncepcją przekładu jako formy wielogłosowej polega na odmiennej „dystrybucji władzy” podmiotów twórczych w tekście. W interpretacjach powieści Dostojewskiego Bachtin przekonywał, że warunkiem stworzenia dzieła polifonicznego jest zrzeczenie się przez autora władzy nad przedstawionymi bohaterami i reprezentowanymi przez nich ideami. Autor w tym ujęciu miałby być tylko jednym $\mathrm{z}$ wielu punktów widzenia, powstrzymującym się od ostatecznych rozstrzygnięć i pozwalającym Innemu przemawiać własnym głosem. Kilkadziesiąt lat później Hermans, pisząc o polifoniczności przekładu, ma raczej na celu podkreślenie suwerenności i równoprawności obydwu podmiotów twórczych obecnych w thumaczonym tekście. Tak więc w odniesieniu do oryginału 
polifoniczność wydaje się koncepcją, która degraduje autora, natomiast na płaszczyźnie przekładu - odwrotnie - służy do wydobycia z cienia podmiotowości tłumacza i uczynienia go twórcą równoprawnym $\mathrm{z}$ autorem dzieła oryginalnego. Mówiąc najprościej: polifonia, w zależności od jej ujęcia, pozwala autorowi zrzec się swojej władzy, a tłumaczowi - „odzyskać" podmiotowość i suwerenność. W obydwu przypadkach istotę polifonii stanowi jednak relacja pomiędzy słowem własnym i słowem cudzym oraz pomiędzy wypowiedzianym i niewypowiedzianym - relacja, która nie zawsze musi być obrazem doskonałej harmonii czy bezkrytycznej aprobaty. Aby ją uchwycić, należy ponad znaczeniem słów dostrzec podmiot (autora/ tłumacza), który słowa cytuje.

\section{Bibliografia}

Bachtin M. 1970. Problemy poetyki Dostojewskiego, przeł. N. Modzelewska, Warszawa: Państwowy Instytut Wydawniczy.

1982. Stowo w powieści, w: M. Bachtin, Problemy literatury i estetyki, przeł.

W. Grajewski, Warszawa: Czytelnik, s. 82-277.

Bolecki W. 1977. Język. Polifonia. Karnawat, „Teksty” 3, s. 7-33.

Bukowski P., Heydel M. (red.) 2009. Wspótczesne teorie przektadu. Antologia, Kraków:

Wydawnictwo Uniwersytetu Jagiellońskiego.

Dębska K. 2012. Tekst polifoniczny jako przedmiot ttumaczenia literackiego, Warszawa: Instytut Lingwistyki Stosowanej Uniwersytetu Warszawskiego.

Hermans T. 2015. Narada języków, thum. zbior., M. Heydel, K. Szymańska (red.), Kraków: Wydawnictwo Uniwersytetu Jagiellońskiego.

Miłosz Cz. 2010. Rosja. Widzenie transoceaniczne. Tom I. Dostojewski-nasz wspótczesny, Warszawa: Zeszyty Literackie.

Pytlak M. 2013. Polifoniczność w przekładzie. O tym jak Polacy i Bułgarzy czytaja „Biesy” Dostojewskiego, Kraków: Wydawnictwo Uniwersytetu Jagiellońskiego.

Ulicka D. 2001. Niektóre problemy poetyki Bachtina, „Teksty Drugie” 6, s. 33-58. 